Int. J. Agril. Res. Innov. Tech. 10(2): 7-14, December 2020 Available online at https://ijarit.webs.com DOI: https://doi.org/10.3329/ijarit.v10i2.51570 https://www.banglajol.info/index.php/IJARIT

\title{
Soil physicochemical properties under eucalyptus tree species planted in alley maize cropping agroforestry practice in Decha Woreda, Kaffa zone, southwest Ethiopia
}

\author{
A. Alemayhu ${ }^{1 *}$ and G. Yakob ${ }^{2}$ \\ Received 29 August 2020, Revised 14 September 2020, Accepted 24 December 2020, Published online 31 December 2020
}

\begin{abstract}
A B S T R A C T
Different studies have shown that the effect of eucalyptus trees on soil physicochemical properties is variable, which indicates that more investigations that focus on different specific geographical locations and eucalyptus tree species are required. The objectives of this study was to evaluate the status of soil nutrients under four eucalyptus tree species planted in hedgerow system in comparison with that in its adjacent open land. To achieve these objectives, soil samples were taken from a soil depth of $0-20 \mathrm{~cm}$ from $15-20$ spots by using auger and composited for respective treatments. Each soil samples analyzed at Teppi soil laboratory following standard procedures. Analysis of variance (ANOVA) and treatments separation were made by using Least Significance Difference (LSD) at 95\% probability level. The analysis result indicated that there were no significance differences between Eucalyptus tree species and its adjacent open land in the level of soil nutrients (total $\mathrm{N}$, available $\mathrm{P}, \mathrm{pH}, \mathrm{OM}$, soil moisture and $\mathrm{OC})(\mathrm{p}<0.05)$. The only significant difference recorded between Eucalyptus tree species and its adjacent open land in the level of sand percentage whereas non-significant difference was noticed between the treatments on the level of silt and clay percentage in the study. Finally, the results indicate that the eucalyptus tree species established in hedgerow system on clay soil in high rainfall area have no significant impact on soil physicochemical properties under short rotation period of the tree species.
\end{abstract}

Keywords: Eucalyptus tree species, Soil physicochemical properties, Soil nutrient.

${ }^{1}$ Natural Resource Management, Bonga Agricultural Research Center, SARI, P. O. Box 101, Ethiopia.

${ }^{2}$ Natural Resource Management, Southern Agricultural Research Institute, SARI, P.O.Box-2126, Ethiopia.

*Corresponding author's email: asratesho6@gmail.com (A. Alemayhu)

Cite this article as: Alemayhu, A. and Yakob, G. 2020. Soil physicochemical properties under eucalyptus tree species planted in alley maize cropping agroforestry practice in Decha Woreda, Kaffa zone, southwest Ethiopia. Int. J. Agril. Res. Innov. Tech. 10(2): 7-14. https://doi.org/10.3329/ijarit.v10i2.51570

\section{Introduction}

Eucalyptus is one of the exotic tree species and most successful plant growing on different environments in Ethiopia and broadly in Africa (Zegeye, 2010). Eucalyptus was planted in Africa initially on the southern African plateaus in the early $19^{\text {th }}$ century to supply fuel wood (Beinart, 2003). During the time, the country has small remnant natural forest thus the only option for fuel wood was eucalyptus (Bennett, 2011). In the 1895, the Emperor of Ethiopia introduced the tree from Australia to address the prevailing fuel wood and construction material demand (Breitenbach, 1961). Still today plantation establishment in Ethiopia is predominantly Eucalyptus (Bekele, 2011) outperforming other exotic and native species due to the fast-growing nature of eucalyptus combined with its widely recognized socio-economic benefits. Many eucalyptus species are easy to cultivate for fuel wood, timber, construction and charcoal due to their ability to coppice readily, tolerance for low quality sites, and low maintenance requirements (Liang et al., 2016).

Evidences on ecological, social and economic importance of the species are emerged in most part of the globe (Bargali. and Singh, 1991; Bargali et al., 1993; Bargali, 1995). Specific concerns focus on potential loss of soil fertility and productivity under short harvest rotations and the associated impact on biodiversity (Jagger and Pender, 2003). The impact of eucalyptus tree plantations upon soil resources has been very much debated and any complete consolidated 
views do not exist, partly because the impact is much dependent on variable site and forest conditions. Both positive and negative effects of Eucalyptus on soil properties were reported by different studies conducted in Ethiopia and elsewhere. A study in highlands of Ethiopia showed that land-use change from agriculture to E. globulus and E. camaldulensis plantation had no adverse impact on exchangeable potassium, total soil nitrogen, phosphorus, and sulphur at least up to the age of $\mathbf{1 4 . 5}$ years (Hailu, 2002). Similarly, no pronounced changes were reported in soil bulk density, organic matter, texture, $\mathrm{pH}$, exchangeable potassium and available water capacity due to Eucalyptus hedgerows along maize farmland in Amhara Region, Ethiopia (Alemie, 2009). Liang et al. (2016) reported higher organic matter and nutrient levels in Eucalyptus plantations in comparison to nearby agricultural land in northern Ethiopia. Evidence from literature suggests the potential of Eucalyptus to reduce soil erosion (Grewal et al., 1992; Kidanu, 2004), sequester carbon in the soil in long term (Silva, 2012) and restore degraded lands through increasing the soil carbon by $37 \mathrm{~g}$ $\mathrm{m}^{-2} \mathrm{yr}^{-1}$ (Lemenih, 2006). A study conducted in central Mozambique revealed that plantations of $E$. grandis increased total soil organic carbon stocks $(0-50 \mathrm{~cm})$ and $\mathrm{N}$ stocks in the top $10 \mathrm{~cm}$ (Guedes et al., 2016). On the contrary, negative effect of Eucalyptus plantation on soil TN, exchangeable $\mathrm{Ca}$ and soil moisture content (Alemie, 2009), and P stocks (Alemie, 2009; Guedes et al., 2016) was reported. It was also reported that Eucalyptus globulus depleted soil nutrients in the central highlands of Ethiopia
(Kindu et al., 2006). This could be due to the combined effect of fast growth and the inability to fix nitrogen (Zegeye, 2010). All these studies can give a clue on the impact of Eucalyptus species on soil. However, site-specific findings on the species may mislead and draw a wrong conclusion. Therefore, this study examine the effect of four eucalyptus tree species on soil physicochemical properties established in hedgerow agro-forestry system in a high rainfall area of South West Ethiopia.

\section{Materials and Methods}

\section{Description of study area}

The study was conducted in Modiyo kebele in Decha district Kaffa zone, south west Ethiopia. The district is located within the latitude of $07^{\circ} 8^{\prime}-$ $07^{\circ} 26^{\prime} \mathrm{N}$ and longitude of $35^{\circ} 53^{\prime}-36^{\circ} 36^{\prime} \mathrm{E}$ (Fig. 1). The altitude and the topography of the study area ranges between 500-2300 meter above sea level consisting of a highly dissected plateau with flat and undulating terrain on areas above 1500 meter above sea level. The dominant soil unit in the study area is Dystric Nitosol (Nd). The study area experience one long rainy season, lasting for 8 months from March to October and the wettest months are between May and August. The mean annual rainfall ranges from $1710 \mathrm{~mm}$ at Bonga station to $1892 \mathrm{~mm}$ at Wushwush station. Over $85 \%$ of the total annual rainfall, with mean monthly values in the range of $125-250 \mathrm{~mm}$ occurs in the 8 months long rainy season. The mean temperature is $19.4^{\circ} \mathrm{C}$ at Bonga and $18.1^{\circ} \mathrm{C}$ at Wushwush station (Bekele, 2003).

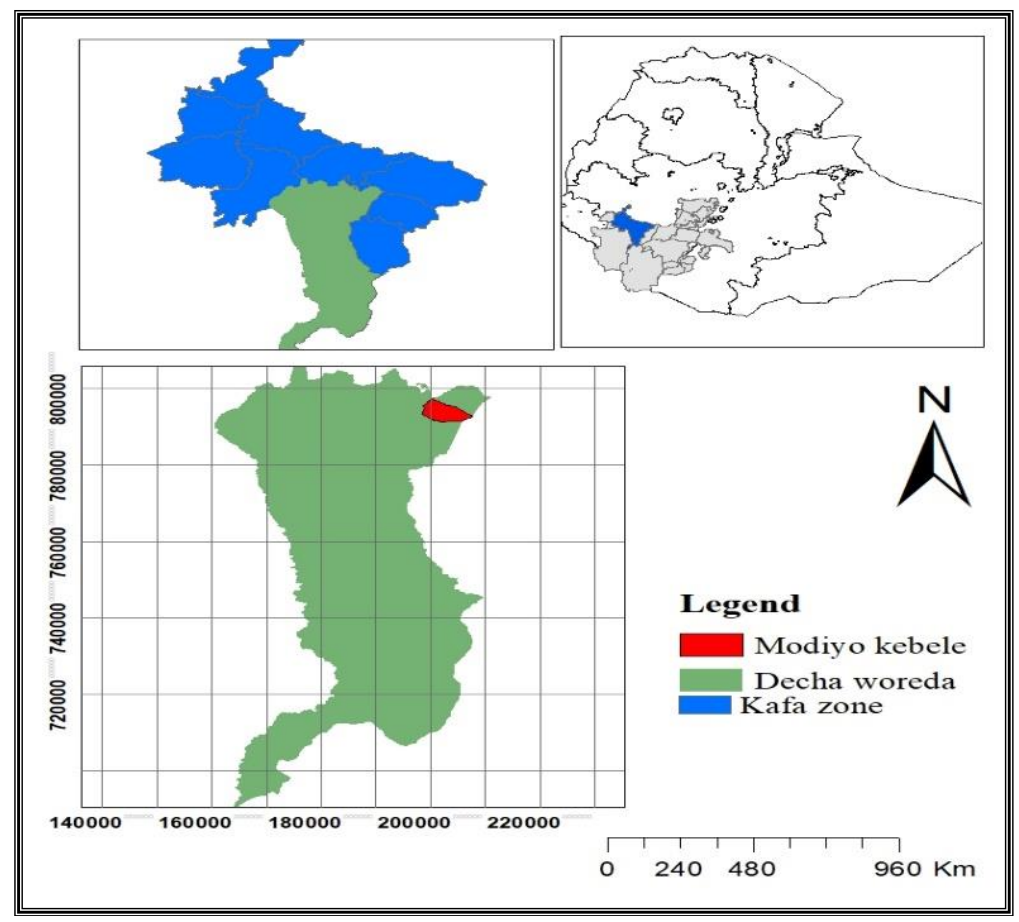

Fig. 1. Map of the study area. 


\section{Plant material and nursery management}

Seeds of Eucalyptus species were obtained from National Forest Research Center, Addis Ababa. Seedlings for the trials were raised at Keyakela nursery site in Kaffa zone from December 2011 to June 2012 close to the study sites. Nursery sowing of the multipurpose species was done on seedbeds and after germination; the seedlings were pricked out into white polythene tubes. A bamboo shed was set up immediately after pricking out to provide shade and was removed as necessary. While in the nursery, the seedlings were watered twice per day during the morning and evening except on days when it rained. This was reduced to once every other day three weeks prior to planting. Weeds were removed on detection and root pruning was done when ever roots out grew the polythene.

\section{Study design and planting}

The study was conducted from 2013 to 2016 on permanent experimental plots laid out in a randomized complete block design with five treatments and three replications to evaluate the effect of Eucalyptus species on physical and chemical characteristics of the soil, which is planted as a hedge. Four eucalyptus tree species were considered as a treatments, Eucalyptus camaldulensis, Eucalyptus citriodora, Eucalyptus grandis and Eucalyptus saligna. In order to establish Eucalyptus hedgerow along the contour Eucalyptus seedlings were planted at the trial sites. Three rows of eucalyptus species with $10 \mathrm{~m}$ distance between rows and $0.5 \mathrm{~m}$ spacing between trees along the row were adopted to establish the hedgerows with a total plot area of $300 \mathrm{~m}^{2}$.

\section{Soil sampling}

Composite soil sample (15-20 spots) from 0-20 $\mathrm{cm}$ soil depth, were taken using auger at (before) planting and end of the trial (from each plot). The collected samples were weighed and air-dried, samples were sifted through a $2 \mathrm{~mm}$ sieve, and approximately $200 \mathrm{~g}$ of every composite sample were sent to laboratory for analysis. Samples were subjected for analysis for texture, $\mathrm{pH}, \mathrm{OC}$, OM, total N, CEC and available $\mathrm{P}$ at Teppi soil laboratory.

\section{Analysis of soil samples}

The soil samples were air dried under the shade, ground using pestle \& mortar and sieved to pass through $2 \mathrm{~mm}$ sieve. The soil $\mathrm{pH}$ (1:2.5 soil/water) was determined in a 1:2.5 soil to water suspension following the procedure outlined by (Sahelemedhin and Taye, 2000). The available phosphorus (AP) was determined following the Olsen procedure (Olsen et al., 1954). Total nitrogen was determined using the micro-Kjeldahl method (Bremner and Mulvaney, 1982), while particle size analysis was carried out using hydrometer method (Bouyoucos, 1962). The organic carbon content was analyzed by wet digestion method using the Walkley and Black oxidation method (Walkley and Black, 1934) while soil organic matter (OM) content was calculated by multiplying soil organic carbon content by a factor of 1.724. The Cation Exchange Capacity (CEC) was determined after extraction of the samples with $1 \mathrm{~N}$ ammonium acetate (Chapman, 1965).

\section{Results and Discussion}

\section{Initial soil physicochemical properties of the experimental sites}

Composite soil sample were taken and subjected for analysis for texture, $\mathrm{pH}, \mathrm{OC}, \mathrm{OM}$, total N, CEC and available $P$.

Table 1. Soil physicochemical properties before planting the eucalyptus tree species in Decha Woreda Kaffa zone southwest Ethiopia.

\begin{tabular}{|l|c|c|}
\hline Soil properties & Values & Soil rating (Landon, 1991) \\
\hline \% OC & 3.76 & High \\
\hline \% OM & 6.48 & High \\
\hline \%TN & 0.32 & High \\
\hline Av. P $(p p m)$ & 12.06 & Low \\
\hline CEC in meq 10og soil-1 & 4.06 & Very Low \\
\hline pH soil $\mathrm{H}_{2} \mathrm{O} 1: 2.5$ & 5.20 & Strongly acidic \\
\hline Textural class & clay & \\
\hline
\end{tabular}

Note: OC-Organic carbon, OM-Organic Matter. TN-Total Nitrogen, Av. P-Available Phosphorus, CEC-Cation Exchange Capacity.

Soil $\mathrm{N}$ content was $0.32 \%$, which is higher than $0.15 \% \mathrm{~N}$ critical level for crops recommended by Sobulo and Osiname (1981). The organic matter was optimum whereas the available phosphorus was very low as ATA's Critical levels used to classify analytical results of soil fertility parameters in southern region. The soil $\mathrm{pH} 5.20$ showed that the soil is strongly acidic. The soil textural class is clay. 


\section{Effects of eucalyptus trees species on soil physical properties}

\section{Soil moisture and soil texture}

Surface soil moisture data were collected by using digital instrument (digital soil moisture tester) directly from the field during maize yield harvesting time every year. The obtained soil moisture data across the treatment was not significant (Table 2). The null difference of the soil moisture under the tree and open area was recorded. Which is may be due to agro-ecological characteristics of the study area in which the area is known with its high moisture and rainfall obtaining up to eight months per year. This result is in line with Alemie (2013) who reported that when there is sufficient rain, eucalyptus tree do not affect the soil moisture, but only when rainfall decreases Eucalyptus dries out the soil faster. In contrary to this, other authors reported the decline of soil moisture near to the Eucalyptus edges (Kidanu et al., 2005; Canisius, 2016).

Table 2. Top soil moisture (percentage) under four Eucalyptus tree species in Decha district Kaffa zone south west Ethiopia.

\begin{tabular}{|l|c|c|c|}
\hline Treatment & \multicolumn{3}{|c|}{ Mean \pm SD } \\
\hline Control & Year I & Year II & Year III \\
\hline Eucalyptus saligna & $14.16 \pm 0.66$ & $12.30 \pm 0.99$ & $13.23 \pm 1.54$ \\
\hline Eucalyptus citriodora & $13.60 \pm 2.08$ & $11.60 \pm 0.88$ & $13.30 \pm 1.21$ \\
\hline Eucalyptus camaldulensis & $13.50 \pm 1.13$ & $12.10 \pm 0.96$ & $13.50 \pm 1.24$ \\
\hline Eucalyptus grandis & $14.10 \pm 1.77$ & $12.40 \pm 1.94$ & $14.10 \pm 1.14$ \\
\hline CV(\%) & $13.50 \pm 1.27$ & $11.90 \pm .89$ & $13.50 \pm 1.71$ \\
\hline LSD (0.05) & 11.70 & 11.10 & 10.50 \\
\hline
\end{tabular}

Note: Mean values with different letters are statistically different at a 0.05.

There were no significant differences in the total silt and total clay percentage between the soil under eucalyptus tree species and the soil out of the eucalyptus tree species (control) but the significant difference was recorded for total sand percentage between the eucalyptus tree species and the control (Table 3 a \& b). The result was nearly similar to the finding by Alemie (2009) who noticed non-significant effect of eucalyptus tree plantation on soil texture in comparisons of soils at different distances and depths.

\section{Effects of eucalyptus trees species on soil chemical properties}

\section{Soil $p H$}

The $\mathrm{pH}$ value of soil under different eucalyptus species was not varied as compared to the control but the value of $\mathrm{pH}$ was varied significantly $(\mathrm{P}<0.05)$ as compared to soil result of before establishment (Table 1, 3 a \& b). The $\mathrm{pH}$ value of the soil revealed an improvement from 5.2 (strongly acidic) to the range between 5.5-5.8 (Moderately Acidic) with maximum improvement of soil acidity under Eucalyptus camaldulensis according to Horneck et al. (2011) classification. The result was in line with Cao et al. (2010)'s finding who reported the reduction of soil $\mathrm{pH}$ from 4.2 to 4.5 , under Eucalyptus spp. plantations in China. Similarly, Alemie (2009) found reduced soil $\mathrm{pH}$ and strongly acidic values ranging from 3.5 to 4.0 under Eucalyptus spp. plantations in Koga watershed in Ethiopia and with (Alemie et al., 2013, Liang et al., 2016)'s report as compared to adjacent agricultural land. The possible case for the improvement of soil $\mathrm{pH}$ may be due to its canopy cover, which may lead to increasing volumes of leaf litter and other organic material available to the soil than relative to agricultural fields (Liang et al., 2016).

In addition, the result was in contrary to Lemenih and Teketay (2004)'s finding who indicated that growing of Eucalyptus increased soil acidity while the base saturation declined compared to native vegetation sites and adjacent agricultural lands.

\section{Soil organic matter}

Soil analysis result indicated that Eucalyptus trees were not affected organic matter content of the experiment site. Moreover, the study revealed the improvement of soil organic matter under the four eucalyptus trees species as compared to before establishment (Table 1, $3 \mathrm{a} \& \mathrm{~b}$ ). organic matter varied from $8.24-10.15 \%$ with an average of approximately $9.18 \%$ and ranged under high level according to (Stephanie et al., 2012), who classified soil OM as low if it is less than $4 \%$, medium if it is between $4 \%$ and $8 \%$ and high if it is above $8 \%$. And the result was in line with Leite et al. (2010) who found in Brazil that contents of soil organic matter were considerably higher in Eucalyptus spp. soils than in pasture areas, which they attributed to the greater amount of residues produced by the Eucalyptus spp. plantation (leaves, branches, bark and especially roots) that remained in the soil. Similarly the finding was in line with Alemie (2009)'s finding who noted that Eucalyptus trees did not affect organic matter content in the soil significantly in comparison along distance from Eucalyptus stand. 
Table 3a. Soil physical and chemical characteristics in eucalyptus vs. maize trial in Decha Woreda, kaffa zone southwest Ethiopia.

\begin{tabular}{|l|c|c|c|c|c|}
\hline Treatments & \%OC & $\% \mathrm{OM}$ & \%TN & Av. P in ppm & CEC in meq 10og soil ${ }^{-1}$ \\
\hline Control & $5.24 \pm 0.80$ & $9.03 \pm 1.38$ & $0.45 \pm 0.07$ & $12.84 \pm 0.40$ & $5.48 \pm 0.75$ \\
\hline E. citriodora & $5.14 \pm 0.80$ & $8.86 \pm 1.39$ & $0.44 \pm 0.07$ & $12.59 \pm 0.34$ & $5.41 \pm 0.78$ \\
\hline E. camaldulensis & $5.54 \pm 1.14$ & $9.55 \pm 1.96$ & $0.47 \pm 0.10$ & $13.07 \pm 0.66$ & $5.78 \pm 1.13$ \\
\hline E. grandis & $4.88 \pm 0.95$ & $8.41 \pm 1.64$ & $0.42 \pm 0.08$ & $12.54 \pm 0.48$ & $5.12 \pm 0.91$ \\
\hline E. saligna & $5.62 \pm 0.93$ & $9.69 \pm 1.60$ & $0.41 \pm 0.05$ & $12.97 \pm 0.42$ & $5.82 \pm 0.90$ \\
\hline P in ANOVA & 0.59 & 0.59 & 0.18 & 0.31 & 0.43 \\
\hline
\end{tabular}

Table 4b. Soil physical and chemical characteristics in eucalyptus vs. maize trial in Decha Woreda, kaffa zone southwest Ethiopia.

\begin{tabular}{|l|c|c|c|c|}
\hline Treatments & pH soil H2O 1:2.5 & Sand (\%) & Silt (\% ) & Clay (\%) \\
\hline Control & $5.6 \pm 0.20$ & $18 \pm 0.11 \mathrm{~b}$ & $34 \pm 3.00$ & $48 \pm 2.30$ \\
\hline E. citriodora & $5.6 \pm 0.23$ & $26 \pm 0.52 \mathrm{a}$ & $20 \pm 11.00$ & $54 \pm 6.42$ \\
\hline E. camaldulensis & $5.7 \pm 0.32$ & $28 \pm 0.57 \mathrm{a}$ & $24 \pm 8.08$ & $48 \pm 5.03$ \\
\hline E. grandis & $5.5 \pm 0.25$ & $28 \pm 0.5 \mathrm{Oa}$ & $16 \pm 8.71$ & $56 \pm 6.11$ \\
\hline E. saligna & $5.7 \pm 0.25$ & $28 \pm 0.57 \mathrm{a}$ & $20 \pm 6.42$ & $52 \pm 1.15$ \\
\hline P in ANOVA & 0.43 & 0.01 & 0.32 & 0.60 \\
\hline
\end{tabular}

Note: Means with different letters are significantly different at $p=0.05$. OC- Organic carbon, OM- Organic Matter, TN-Total Nitrogen, Av. P-Available Phosphorus, CEC-Cation Exchange Capacity.

\section{Soil available phosphorus and total nitrogen}

The mean concentration of soil available $\mathrm{P}$ recorded were 12.84 and $12.59,13.07,12.54$, 12.97 ppm for control and Eucalyptus tree species, respectively (Table 3 a) but the difference was not significant. The soil analysis result revealed that the eucalyptus trees species was not affected the concentration of soil available phosphorus as compared to the control and precropping soil analysis in the study area. Moreover, the study revealed the improvement of soil available $\mathrm{P}$ under the four eucalyptus trees species as compared to before establishment (Table 1, 3 a). Similarly, there were no significant differences in the level of the concentration of soil total nitrogen between the soil under the eucalyptus tree species and the control. However, the soil analysis result revealed the improvement of total nitrogen concentration in the soil as compared to pre-cropping soil analysis result in the trial (Table 1, 3 a). This improvement could also be explained by the significantly different quantities of organic matter, due to the obvious difference in leaf litter (Liang et al., 2016).

As organic matter input increases in the soil due to increased litter falling from the forest or plantation canopy, microorganisms break down the organic matter, generating more nutrients, including nitrogen and phosphorus (Bot and Benites, 2005). Both nitrogen and phosphorus are associated with the amount of organic matter found in soil, as organic matter acts as a major source of nutrients to the soil (Brady, 1990). Nitrogen and phosphorus levels were higher under Eucalyptus camaldulensis than agricultural land, where there are also higher amounts of organic matter. The result was in line with Yitaferu et al. (2013)'s finding who founded greater total nitrogen concentration in eucalyptus land use than others. In addition, in contrary with Alemie (2009) who found decreased total nitrogen concentration under plantations of Eucalyptus spp. in Ethiopia and Tererai et al. (2014) in South Africa. Results of the present experiment are not in agreement with Yitaferu et al. (2013) and Alemie (2009).

Soil organic carbon and cation exchange capacity The concentration of soil organic carbon revealed an improvement as compared to initial value of organic carbon from $3.76 \%$ to minimum $4.88 \%$ under Eucalyptus grandis and maximum 5.62\% under Eucalyptus saligna (Table 3 a). Our data of soil organic carbon were supported by the findings of Bekele et al. (2006), who showed that E. grandis plantation, after 20 years of cultivation and 35 years of pasture, increased the total soil organic carbon to nearly predeforestation levels. Likewise, Ashagrie et al. (2005) found out that the bulk of soil organic carbon of E. globulus plantation at age of 21 was as similar as with that of its adjacent natural forest. These findings in combination with the prior studies can indicate that eucalyptus tree species included in this study has the potential to improve the soil organic carbon. Similar to OC, cation exchange capacity was improved as compared to initial value from 4.06 to minimum 5.12 under Eucalyptus grandis and maximum 5.82 under Eucalyptus saligna and the value of cation exchange capacity in our study was an unusual in the soil with high organic matter and clay soil texture (Table 3 a \& b). 
As our result was in line with some authors finding (Cao et al., 2010; Leite et al., 2010; Bekele et al., 2006; Ashagrie et al., 2005), there is also the contradiction with a few comparative studies on soil nutrient under exotic plantations (E. globulus, E. grandis, E. saligna, Pinus patula and $C$. lustanica) and other land use (Betre et al., 2000; Michelsen et al., 1996; Maro et al., 1991). Those studies showed that $\mathrm{pH}$, total $\mathrm{N}$, available $\mathrm{P}$ and some other nutrient contents of soil in the adjacent natural forest soil were higher than those in soil of the certain plantations. Possible causes of the difference with the present study might be associated with the location of the plantation, age of the plantation, forest management activities and microclimatic condition.

\section{Conclusion and Recommendations}

The evaluation of the effect of eucalyptus tree species on the soil physicochemical properties in high rainfall area was brought non-significant impact on soil nutrients in the study area. However, there is even a slight improvement of soil nutrients under the eucalyptus tree species as compared to the opened land in some cases and before establishment of soil sample analysis in all cases. The soil pH was improved as compared to before and after the trial respectively and high improvement was recorded the soil under Eucalyptus camaldulensis and Eucalyptus saligna than the remaining treatments. Similar to soil $\mathrm{pH}$, soil organic carbon and soil organic matter have revealed an improvement in comparison with before soil analysis and relatively the higher value was recorded in soil under Eucalyptus camaldulensis and Eucalyptus saligna, which is a good indication of soil improvement under the eucalyptus tree species in the short rotation system. The concentration of total nitrogen and available phosphorus followed the same manner to organic carbon and organic matter, but the difference is the concentration of total nitrogen was the least under Eucalyptus saligna as compared to other treatments. The percentage of clay and silt particles was not significantly affected by the eucalyptus tree species while the slight significant difference was recorded on the percentage of sand. Therefore, the study concludes that growing eucalyptus tree species in hedgerow or boundary planting for short rotation period in high rainfall area does not affect the concentration of soil nutrients of soil physicochemical properties. Our suggestions for future research should plan to test the soil over a long period to see any major differences.

\section{References}

Alemie, T.C, Collick, A.S., Adgo, E., Lehmann, C.J. and Steenhuis, T.S. 2013. Eco- hydrological impacts of Eucalyptus in the semi humid Ethiopian Highlands: the Lake Tana Plain. J. Hydrol. Hydromech. 61(1): 21-29. https://doi.org/10.2478/johh-2013-0004

Alemie, T.C. 2009. The effect of Eucalyptus on crop productivity, and soil properties in the Koga Watershed, Western Amhara Region, Ethiopia. M.Sc. Thesis, Faculty of the Graduate School of Cornell University. 6o p.

Ashagrie, Y., Zech, W. and Guggenberger, G. 2005. Transformation of a Podocarpus falcatus dominated natural forest into a monoculture Eucalyptus globulus plantation at Munesa, Ethiopia: soil organic $\mathrm{C}, \mathrm{N}$ and $\mathrm{S}$ dynamics in primary particle and aggregate-size fractions. Agric. Ecosys. Environ. 106: 89-98. https://doi.org/10.1016/j.agee.2004.07.015

Bargali, S.S. 1995. Efficiency of nutrient utilization in an age series of Eucalyptus tereticornis plantations in the Tarai belt of central Himalaya. J. Trop. Forest Sci. 7(3): 383-390.

Bargali, S.S. and Singh, S.P. 1991. Aspect of productivity and nutrient cycling in an 8year old Eucalyptus plantation in a moist plain area adjacent to Central Himalaya, India. Canadian J. Forest Res. 21: 13651372. https://doi.org/10.1139/x91-193

Bargali, S.S., Singh, S.P. and Singh, R.P. 1993. Pattern of weight loss and nutrient release in decomposing leaf litter in an age series of Eucalyptus plantations. Soil Biol. Biochem. 25: 1731-1738. https://doi.org/10.1016/oo380717(93)90177-D

Beinart, W. 2003. The rise of conservation in South Africa: settlers, livestock and the environment 1770-1950. Oxford University Press. 96p.

Bekele, L., Dan, B.K., Ingvar, N. and Mats, O. 2006. Soil carbon sequestration under different exotic tree species in the southwestern highlands of Ethiopia. Geoderma. 136: 886-898.

https://doi.org/10.1016/j.geoderma.2006.06.008

Bekele, M. 2011. Forest plantation and woodlots in Ethiopia. African forest forum working paper series. African Forest Forum. 12(1): 156.

Bekele, T. 2003. The potential of Bonga Forest for certification: a case study. In: National Stakeholders Workshop on Forest Certification: Organized by Institute of Biodiversity Conservation and Research (IBCR), FARM Africa and SOS Sahel. pp. 121

Bennett, M.B. 2011. Global history of Australian trees. J. History Biol. 44: 125-145. https://doi.org/10.1007/s10739-010-9243-7

Betre, A., Tekalign, M. and Larsson, R. 2000. Effects of natural forest conversion to plantation and secondary forests on soil 
chemical properties in Munessa montane forest, Ethiopia. Ethiopian J. Nat. Res. 2: $165-187$.

Bot, A. and Benite, J. 2005. The importance of soil organic matter. Key to drought-resistant soil and sustained food and production. FAO, Soils bulletin 80, Viale delle Terme di Caracalla 00100, ISBN 92-5-105366-9, Rome, Italy. $78 \mathrm{p}$.

Bouyoucos, G.J. 1962. Hydrometer method improvement for making particle size analysis of soils. Agron. 5: 179-186. https://doi.org/10.2134/agronj1962.0002196200 5400050028x

Brady, N.C. 1990. The Nature and Properties of Soils. New York: Macmillan Publishing Company. pp. 91-152.

Breitenbach, F. 1961. Exotic forest trees in Ethiopia. Addis Ababa, Ethiopian Forestry Association. Ethiopian Forest Rev. 2: 19-39.

Bremner, J.M. and Mulvaney, C.S. 1982. Total Nitrogen. In: Page, A.L., Miller, R.H., Keeney, D.R. (eds). Methods of Soil Analysis. II. Chemical and Microbiological Properties. American Society of Agronomy, Soil Science Society of America. pp. 595624 .

Canisius, P.M. 2016. The use of Eucalyptus in agroforestry systems of southern Rwanda: to integrate or segregate? PhD Thesis, Wageningen University, Netherlands. 162p.

Cao, Y., Fu, S., Zou, X., Cao, H., Shao, Y. and Zhou, L. 2010. Soil microbial community composition under Eucalyptus plantations of different age in subtropical China. European J. Soil Biol. 46(2): 128-135. https://doi.org/10.1016/j.ejsobi.2009.12.006

Chapman, H.D. 1965. Cation Exchange Capacity. In: Black, C.A., Ensminger, L.E., Clark, F.E. (eds). Methods of Soil Analysis, Agronomy Inc., Madison, Wisconsin. 9: 891-901. https://doi.org/10.2134/agronmonogr9.2.c6

Grewal, S.S., Mittal, S.P., Dyal, S. and Agnihotri, Y. 1992. Agroforestry systems for soil and water conservation and sustainable production from foothill areas of north India. Agrofor. Syst. 17(3): 183-191.

Guedes, B.S., Olsson, B.A. and Karltun, E. 2016. Effects of 34-year-old Pinus taeda and Eucalyptus grandis plantations on soil carbon and nutrient status in former miombo forest soils. Global Ecol. Conserv. 8: 190-202.

https://doi.org/10.1016/j.gecco.2016.09.005

Hailu, Z. 2002. Ecological impact evaluation of eucalyptus plantations in comparison with agricultural and grazing land-use types in the highlands of Ethiopia. Doctoral Thesis, University of Natural Resources and Life Sciences, Boku, Vienna. 271p.

Horneck, D.A, Sullivan, D.M., Owen, J.S. and Hart, J.M. 2011. Soil Test Interpretation
Guide. Oregon State University, Extension Service, July, 1-12. Retrieved from http://extension.oregonstate.edu/sorec/site s/default/files/soil_test_interpretation_ec1 478.pdf.

Jagger, P. and Pender, J. 2003. The role of trees for sustainable management of less-favored lands: the case of Eucalyptus in Ethiopia. Forest Policy and Econ. 5(1): 83-95. https://doi.org/10.1016/S1389-9341(01)ooo78-8

Kidanu, S. 2004. Using Eucalyptus for soil and water conservation on the highland Vertisols of Ethiopia. PhD Dissertation, ISBN 905808-993-2, No. 52. Wageningen University, Netherland. 197 p.

Kidanu, S., Mamo, T. and Stroosnijder, L. 2005. Biomass production of Eucalyptus boundary plantations and their effect on crop productivity on Ethiopian highland Vertisols. Agroforest. Forum. 63: 281-290. https://doi.org/10.1007/s10457-005-5169-Z

Kindu, M., Glatzel, G., Tadesse, Y. and Yosef, A. 2006. Tree species screened on Nitosols of central Ethiopia: Biomass production, nutrient contents and effects on soil nitrogen. J. Trop. Forest Sci. 18: 87-90.

Landon, J.R. 1991. Brooker Tropical Soil Manual. A Handbook for Soil Survey and Agricultural Land Evaluation in the Tropics and Subtropics. John Wiley \& Sons, Inc., New York, USA. 474p.

Leite, F.P., Silva, I.R., Ferreira, R., de Barros, N. F. and Neves, L.J.C. 2010. Alterations of Soil Chemical Properties by Eucalyptus Cultivation in Five Regions in the Rio Doce Valley. Forest Ecol. Manage. 1: 821-831. https://doi.org/10.159o/So100-06832010000300024

Lemenih M. 2006. Expediting ecological restoration with the help of foster tree plantations in Ethiopia. J. Drylands. 1(1): 72-84.

Lemenih, M. and Teketay, D. 2004. Restoration of native forest flora in the degraded highlands of Ethiopia: constraints and opportunities. SINET: Ethiopian J. Sci. 27(1): 75-90.

https://doi.org/10.4314/sinet.v27i1.18225

Liang, J., Reynolds, T., Wassie, A., Collins, C. and Wubalem, A. 2016. Effects of exotic Eucalyptus spp. plantations on soil properties in and around sacred natural sites in the northern Ethiopian Highlands. AIMS Agric. Food. 1(2): 175-193.

https://doi.org/10.3934/agrfood.2016.2.175

Maro, R.S., Chamshama, S.A.O., Nsolomo, V.R. and Maliondo, S.M. 1991. Soil chemical characteristics in a natural forest and Cupressus lustanica plantation at west Kilimanjaro, Northern Tanzania. J. Trop. Forest Sci. 5: 465-472.

Michelsen, A., Lisanework, N., Friis, I. and Holst, N. 1996. Comparisons of understory 
vegetation and soil fertility in plantations and adjacent natural forests in the Ethiopian Highlands. J. Appl. Ecol. 33: 627-642. https://doi.org/10.2307/2404991

Olsen, S.R., Cole, C.V., Watanable, F.S., Dean, L.A. 1954. Estimation of available phosphorus in soil by extraction with sodium bicarbonate. USDA Circular. 939(1): 19.

Sahlemeden, S. and Taye, B., 2000. Procedure for soil and land analysis. National Soil Research Center, Ethiopia Agricultural research organization, Addis Ababa, Ethiopia. 110p.

Silva, D. 2012. Impact of Eucalyptus plantations on pastureland on soil properties and carbon sequestration in Brazil. MSc Thesis, Swedish University of Agricultural Sciences, Uppsala, SLU. 19p.

Sobulo, R.A. and Osiname, O.A. 1981. Soils and fertilizer use in Western Nigeria. Tech. Bull. 11: 8-9.

Stephanie, M., Daniel, G., Loren, S.M. and Joseph, R.H. 2012. Soil organic matter level and interpretation. Fact Sheet FS1136.
Rutgers, The State University of New Jersey 57 US Highway 1, New Brunswick, NJ o8901-8525. pp. 1-3.

Tererai, F., Gaertner, M., Jacobs, S.M. and Richardson, D.M. 2014. Eucalyptus camaldulensis invasion in riparian zones reveals few significant effects on soil physicochemical properties. River Res. Appl. 7(4): 1-12.

Walkley, A. and Black, C.A. 1934. An examination of the digestion method for determining soil organic matter and a proposed modification of the chromic acid titration method. Soil Sci. 37: 29-38.

https://doi.org/10.1097/00010694-193401000-00003

Yitaferu, B., Abewa, A. and Amare, T. 2013. Expansion of Eucalyptus woodlots in the fertile soils of the highlands of Ethiopia: Could it be a treat on future cropland use? $J$. Agril. Sci. 5(8): 97-103. https://doi.org/10.5539/jas.v5n8p97

Zegeye, H. 2010. Environmental and socioeconomic implications of Eucalyptus in Ethiopia. Ethiop. Inst. Agric. Res. pp. 184205. 